\title{
Baccharis crispa attenuates toxic hepatitis induced by acetaminophen and carbon tetrachloride in mice
}

Ana Magdalena Velázquez, Elena Maria Goretti Diarte, Olga Yolanda Heinichen, Yenny Montalbetti, Miguel Ángel Campuzano-Bublitz, Maria Luisa Kennedy, Maria del Carmen Hellion-Ibarrola, Derlis Alcides Ibarrola*

Department of Pharmacology, Faculty of Chemical Sciences. National University of Asuncion. Campus UNA, 2169. San Lorenzo, Paraguay.

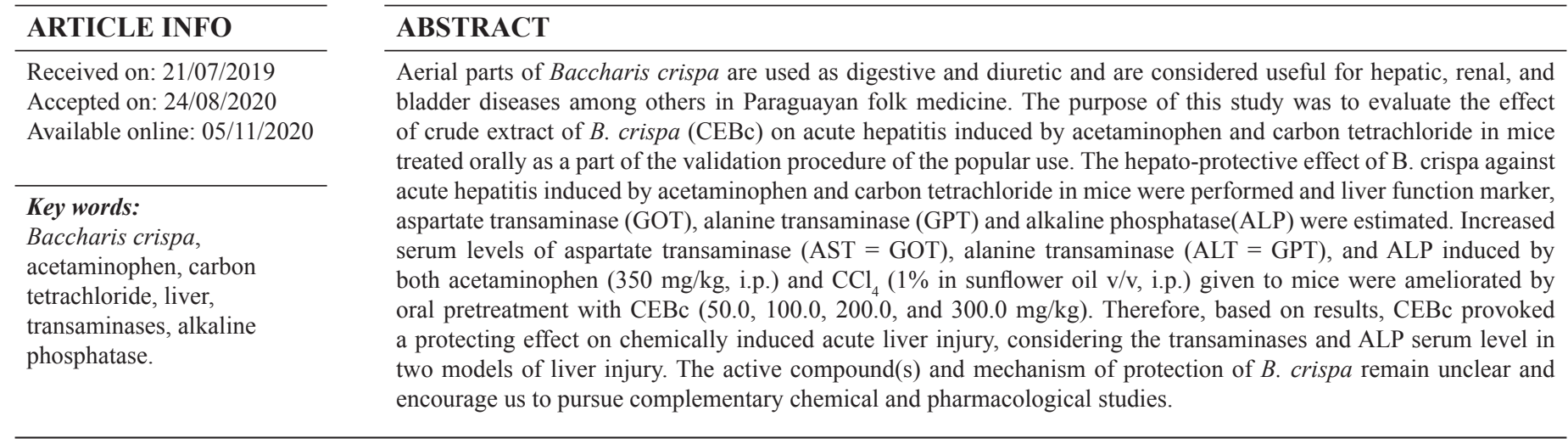

\section{INTRODUCTION}

There is little doubt about the health value of traditional medicine around the world. According to the World Health Organization (World Health Organization, 2013), herbal medicine, traditional treatments, and traditional practitioners are the main source of healthcare and sometimes the only source of care. In Paraguay, herbal medicine is culturally accepted, accessible, in proximity or cultivated into home garden, affordable, and trusted by the population. However, unfocalized efforts from either health policymakers, academicians, or researchers contribute poorly to the availability of traditional medicine of proven quality, safety, and efficacy. In Paraguay, where medicine is lacking, medicinal plants are collected from wild sources and there is no plan for

"Corresponding Author

Derlis Alcides Ibarrola, Department of Pharmacology, Faculty of

Chemical Sciences. National University of Asuncion. Campus UNA, 2169.

San Lorenzo, Paraguay.E-mail: dibarrol@qui.una.py good agronomical practice, thus compromising conservation and sustainability of future medicine.

Many herbs have been used in clinical practice for centuries as natural remedies, either for preventing or for the treatments of liver diseases in both western and eastern populations. Among the many hepatoprotective herbs/compounds, Silybum marianum (milk thistle), glycyrrhizin, Bupleurum chinense, Schisandra chinensis, and Phyllanthus amarus have been most widely studied and documented (Wang et al., 2007).

The genus Baccharis is claimed to possess a pain reliever activity in the southern area of Brazil (Stolz et al., 2014). Baccharis crispa, Baccharis trimera, and Baccharis microcephala are commercialized in Paraguay under the Guarani name of jaguareteka'a. Preparation from aerial parts is used as digestives and diuretics (Ibarrola et al., 2011) and is considered useful for hepatic, renal, and bladder disease among others in Paraguayan folk medicine (Basualdo et al., 2004; Caceres and Machaín, 2000). In Brazil, it is claimed popularly that $B$. crispa is useful in diabetes mellitus (Salgueiro et al., 2018). The hepatoprotective effect of $B$. trimera against acetaminophen (APAP, N-acetyl-p-aminophenol)induced toxic hepatitis has been proved (Pádua et al., 2014). Also, 
a significant free radical scavenging activity in aqueous extracts obtained from aerial parts of Baccharis cordifolia and B. crispa (Asteraceae) correlating to a significant antioxidant activity was found (Desmarchelier et al., 1997). Besides, an antimicrobial effect of $B$. trimera against gram-positive and gram-negative bacteria (Staphylococcus aureus, Escherichia coli, Klebsiella pneumoniae, and Pseudomonas aeruginosa) and fungus (Candida albicans) has been verified (da Silva et al., 2018). Gastroprotective and curative effects of $B$. trimera in rats submitted to experimental ulcers induced by ethanol and acetic acid were denoted (Aparecida et al., 2016). Phytochemical analysis of B. crispa revealed the presence of saponins, flavonoids, sugar, and glycosides. Recently, we were able to show a gastrointestinal prokinetic activity of crude extract of B. crispa (CEBc) in mice (Velázquez et al., 2019).

Oxidative damage and lipid peroxidation are common chemical injuries induced to liver cells. Drugs commonly responsible for chemical injuries to liver cells are antibiotics, nonsteroidal anti-inflammatories, and psychotropic drugs (Mayoral and Lewis, 2000). Acetaminophen and carbon tetrachloride are common chemicals used for the induction of acute hepatitis for an experimental purpose (Lancaster et al., 2015; McGill and Jaeschke, 2018). Rats are very resistant to acetaminophen-induced hepatic damage in comparison to mice (McGill et al., 2012). The aim of this study was to evaluate the influence of B. crispa on acute hepatitis induced by acetaminophen and carbon tetrachloride in mice treated orally as a part of the validation procedure of its popular use.

\section{MATERIALS AND METHODS}

\section{Plant material and extract preparation}

Aerial parts of cultivated B. crispa Spreng were collected in Villeta, Paraguay. A voucher specimen was authenticated at the herbarium of the Faculty of Chemical Sciences, National University of Asunción, and was deposited under code CC \& AV 1,322. Fresh samples were dried in an oven at $38^{\circ} \mathrm{C}$ and ground to fine powder. This powder was extracted with ethanol by a conventional reflux method for 1 hour, then filtered, and evaporated under reduced pressure. The ethanolic extract of $B$. crispa $(\mathrm{Bc})$ was stored at room temperature in a desiccator until use. This semisolid extract was used in all biological tests.

\section{Reagents and drugs}

Chemicals of analytical grade were used for the pharmacological assay. Sodium chloride (WAKO Pure Chemical Industries Ltd., Japan), carbon tetrachloride (Biopack), paracetamol and silymarin (Sigma Chemical Company, St. Louis, MO), sodium pentobarbital (Nembutal Abbott Laboratory, Japan), and ethanol (submitted to glassware distillation before use) and propylene glycol were acquired locally.

\section{Animals}

Swiss albino male mice weighing 25 and $35 \mathrm{~g}$ were obtained from the Bioterium of the Faculty of Chemical Sciences (National University of Asunción). The animals were kept in a room with controlled light/dark cycles (12 hours), temperature $\left(23^{\circ} \mathrm{C} \pm 2^{\circ} \mathrm{C}\right)$, and relative humidity $(50 \%-60 \%)$ to avoid environmentally originated factors affecting animal behavior. The animals received commercial foods and were fasted overnight before the experiments; they had free access to drinking water during the trials. All experimental practices performed in the present work were directed in agreement with the international standards of animal welfare and the protocol was previously approved by the institutional Ethical Committee in Scientific Research of the Faculty of Chemical Sciences on March 2, 2015 (CEI-188-15).

\section{Acetaminophen-induced hepatotoxicity and treatment}

The animals were randomly allocated into seven different experimental groups of six mice each. A pilot study was performed to set up the effective dose of acetaminophen (APAP, $\mathrm{N}$-acetyl-p-aminophenol or paracetamol), which increased serum transaminases and alkaline phosphatase levels in mice. Druginduced acute hepatotoxicity was provoked by an intraperitoneal injection of $350.0 \mathrm{mg} / \mathrm{kg}$ of APAP as described in Wu et al. (2008), with small modifications. Briefly, two groups received vehicle $(2.5 \%$ of ethanol in distilled water) and five other groups received, respectively, silymarin $(100.0 \mathrm{mg} / \mathrm{kg}$ p.o.) and $\mathrm{CEBc}$ $(50.0,100.0,200.0$, and $300.0 \mathrm{mg} / \mathrm{kg}$, p.o.) as pretreatments. Thirty minutes later, all groups except the first one (vehicle) were given intraperitoneally $350.0 \mathrm{mg} / \mathrm{kg}$ of acetaminophen (APAP). After 4 hours, all animals were submitted to total blood collection according to individual timing. Previously, a deep pentobarbital $(50.0 \mathrm{mg} / \mathrm{kg}$, i.p.) anesthesia was induced and an intracardiac puncture was done, followed by cervical dislocation. Serum was separated and aspartate transaminase $(\mathrm{AST}=\mathrm{GOT})$, alanine transaminase $(\mathrm{ALT}=\mathrm{GPT})$, alkaline phosphatase (ALP) were measured.

\section{Carbon tetrachloride-induced hepatotoxicity and treatment}

The animals were assigned randomly into seven different groups of six mice each. Acute hepatotoxicity was provoked by oral administration of $1 \%$ carbon tetrachloride $(v / v)$ dissolved in sunflower oil as described in Sun et al. (2018), with some modifications. Briefly, two groups received vehicle $(2.5 \%$ of tween 80 in distilled water) and distilled water $(0.1 \mathrm{ml} / 10 \mathrm{~g} \mathrm{bw})$, respectively. The other five groups received silymarin $(100.0 \mathrm{mg} /$ $\mathrm{kg}$, p.o.) and $\operatorname{CEBc}(50.0,100.0,200.0$, and $300.0 \mathrm{mg} / \mathrm{kg}$, p.o.), respectively, as pretreatments once a day for 5 days. One hour after the last administration, the control group was treated orally with sunflower oil $(0.1 \mathrm{ml} / 10 \mathrm{~g} \mathrm{bw})$ and all other groups were administered orally with $1 \%$ carbon tetrachloride $(0.1 \mathrm{ml} / 10 \mathrm{~g} \mathrm{bw})$. After 4 hours, all animals were submitted to total blood collection according to individual timing. Previously, a deep pentobarbital $(50.0 \mathrm{mg} / \mathrm{kg}$, i.p.) anesthesia was induced and an intracardiac puncture was done, followed by cervical dislocation. Serum was separated and aspartate transaminase $(\mathrm{AST}=\mathrm{GOT})$, alanine transaminase $(\mathrm{ALT}=\mathrm{GPT}), \mathrm{ALP}$ levels were measured

\section{Statistical analysis}

The results were expressed as mean \pm standard deviation (SD) and one-way analysis of variance (ANOVA), followed by Dunnett's multiple comparisons test, which was performed using GraphPad Prism version 7.0 for Windows, GraphPad Software, La Jolla, CA. The values of $\mathrm{p}<0.05$ were considered as statistically significant. 


\section{RESULTS}

\section{Effect of CEBc on acetaminophen-induced hepatotoxicity} in mice

Considering the serum level of GPT, GOT, and ALP of mice treated with different doses of CEBc, a clear liver protective effect was denoted. Certainly, CEBc given orally to mice $(50.0,79$ $\pm 10.8 ; 100.0,75.2 \pm 16.8 ; 200.0,52.8 \pm 13$; and 300.0, $58.33 \pm 5.6$, $\mathrm{mg} / \mathrm{kg}$ and U/L, respectively; $p<0.0001$ ) significantly reduced the APAP-induced elevation of the serum level of GPT $(\mathrm{U} / \mathrm{L})$ as far as $59 \%$. Similarly, $100.0 \mathrm{mg} / \mathrm{kg}$ of silymarin $(64 \pm 6.2 \mathrm{U} / \mathrm{L}$, positive control) induced a significant protecting effect on liver damage visualized by a reduced serum GPT level in comparison to pathological control $(129.2 \pm 31.3 \mathrm{U} / \mathrm{L})$ by $50 \%$. Besides, the group of animals treated with APAP $(350.0 \mathrm{mg} / \mathrm{kg})$ denoted an increase in GPT serum level by $420 \%$, significantly different from vehicletreated animals $(30.83 \pm 5.6 \mathrm{UI} / \mathrm{L} ; p<0.0001)$, both validating the methods used (Fig. 1). Interestingly, 200.0 and $300.0 \mathrm{mg} / \mathrm{kg}$ of CEBc provoked a similar hepatoprotective effect as silymarin.

Likewise, the elevation of serum level of GOT induced by APAP was significantly attenuated in mice orally pretreated, respectively, with CEBc (50.0, $200.6 \pm 35.6$; 100.0, $145 \pm 66.2$; $200.0,112 \pm 58$; and $300.0,222.8 \pm 26.0, \mathrm{mg} / \mathrm{kg}$ and U/L) and silymarin $(204.2 \pm 76.2 \mathrm{U} / \mathrm{L})$. The most potent liver-protecting effect of $74 \%$ was observed with $200.0 \mathrm{mg} / \mathrm{kg}$ of CEBc in comparison to APAP-induced GOT increase in mice (Fig. 2). Similarly, 100.0 $\mathrm{mg} / \mathrm{kg}$ of silymarin (204 $\pm 76 \mathrm{U} / \mathrm{L}$, positive control) induced a significant protecting effect on liver damage visualized by a reduced serum GOT level in comparison to pathological control $(433 \pm 263$ $\mathrm{U} / \mathrm{L}$ ) by $53 \%$. Additionally, the same doses of CEBc diminished significantly the transaminases and ALP increase was induced by APAP in mice in a more effective way than silymarin (Fig. 3). Indeed, the elevation of serum level of ALP induced by APAP was

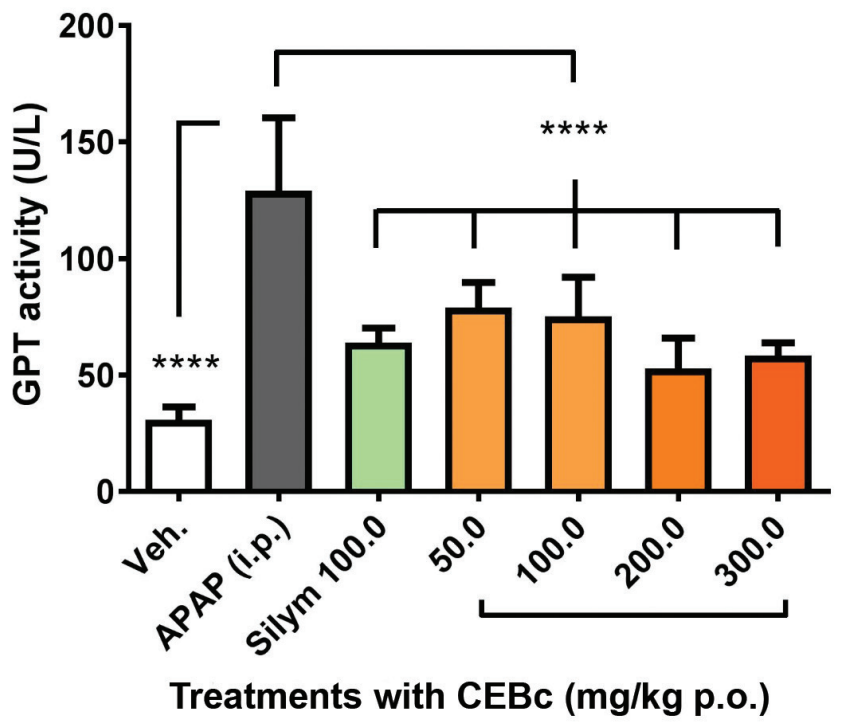

Figure 1. Influence of B. crispa (CEBc) given orally to mice on serum GPT activity (U/L) after acute hepatitis induced by paracetamol (APAP $350 \mathrm{mg} / \mathrm{kg}$ ). Each bar represents the mean $\pm \mathrm{SD}(n=6)$. Statistical analysis was performed using ANOVA, followed by Dunnett's multiple comparison test. $* * * * p<$ 0.0001 , significantly different from vehicle (Veh.). significantly attenuated in mice orally pretreated with CEBc (50.0, $300 \pm 20 ; 100.0,105 \pm 52 ; 200.0,77 \pm 34$; and 300.0, $233 \pm 24, \mathrm{mg} /$ $\mathrm{kg}$ and $\mathrm{U} / \mathrm{L}$, respectively) and silymarin $(131 \pm 58 \mathrm{U} / \mathrm{L})$.

\section{Effect of CEBc on carbon tetrachloride-induced hepatotoxicity in mice}

A clear liver-protective effect was denoted since increased serum levels of GPT, GOT, and ALP induced by $\mathrm{CCl}_{4}$ in mice were attenuated with different oral doses of CEBc. In concordance with the protective effect observed with CEBc in the liver injury induced by APAP, undoubtedly oral administration of CEBc (50.0, $234.3 \pm$ $55.37 ; 100.0,594.3 \pm 280.9 ; 200.0,560 \pm 280.3 ;$ and 300.0, $679.6 \pm$ $179.1, \mathrm{mg} / \mathrm{kg}$ andU/L, respectively; $p<0.0001$ ) for 5 days to mice significantly reduced the $\mathrm{CCl}_{4}$-induced elevation of the serum level of GOT by $73 \%$. Similarly, $100.0 \mathrm{mg} / \mathrm{kg}$ of silymarin $(287 \pm 81.77$ $\mathrm{U} / \mathrm{L}$; positive control) induced a significant protecting effect on liver damage visualized by a reduced serum GPT level in comparison to pathological control $(859.5 \pm 287.3 \mathrm{U} / \mathrm{L})$ by $67 \%$. Besides, the group of animals treated with $\mathrm{CCl}_{4}(1 \%)$ denoted an increase in GOT serum level by $687 \%$, significantly different from vehicle-treated animal $(109.2 \pm 19.87 \mathrm{U} / \mathrm{L} ; * * * * p<0.0001)$, both validating the method used (Fig. 4). The dose of $50.0 \mathrm{mg} / \mathrm{kg}$ of CEBc provoked a more intense $(73 \%)$ protection than silymarin $(67 \%)$.

Likewise, unquestionably, $50.0 \mathrm{mg} / \mathrm{kg}$ of $\mathrm{CEBc}$ given $(5$ days) orally to mice significantly reduced the $\mathrm{CCl}_{4}$-induced elevation of serum level of GPT ( $400 \pm 150 \mathrm{U} / \mathrm{L})$ by $52 \%$. Similarly, 100.0 $\mathrm{mg} / \mathrm{kg}$ of silymarin $(427 \pm 144.5 \mathrm{U} / \mathrm{L}$, positive control $)$ induced a significant protecting effect on liver damage visualized by a reduced serum GPT level in comparison to the pathological group (830.3 $\pm 149.7 \mathrm{U} / \mathrm{L}$ ) by $49 \%$. Besides, the group of animals treated with $\mathrm{CCl}_{4}(1 \%)$ denoted an increase in GPT serum level by $2,128 \%$, significantly different from vehicle-treated animal (39 \pm 17 ; $p<$ $0.0001)$, both validating the method used (Fig. 5). B. crispa $(50.0$

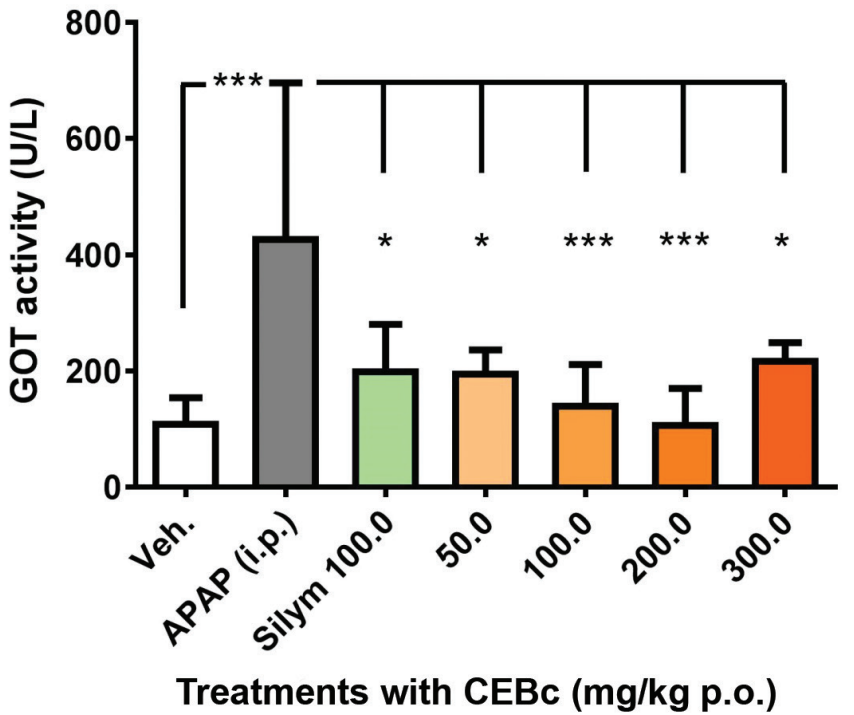

Figure 2. Influence of $B$. crispa (CEBc) given orally on serum GOT activity $(\mathrm{U} / \mathrm{L})$ of mice after acute hepatitis induced by acetaminophen (APAP $350 \mathrm{mg}$ ) $\mathrm{kg})$. Each bar represents the mean $\pm \mathrm{SD}(n=6)$. Statistical analysis was performed using ANOVA, followed by Dunnett's multiple comparison test. $* * * p<0.0002$; $* p<0.0332$, significantly different from vehicle (Veh.). 
$\mathrm{mg} / \mathrm{kg}$, p.o.) provoked protection at a similar intensity compared with silymarin. In contrast, 5 days of treatment with higher doses of CEBc (100.0, $927 \pm 62 ; 200.0,634 \pm 253$; and 300.0, $579 \pm 109$, $\mathrm{mg} / \mathrm{kg}$; U/L, respectively) did not modify the GPT level which increased after liver injury induced by $\mathrm{CCl}_{4}$. We have no knowledge about this response and speculate that this maybe is due at least to the severity of injury induced by $\mathrm{CCl}_{4}$ in comparison to damage induced by APAP.

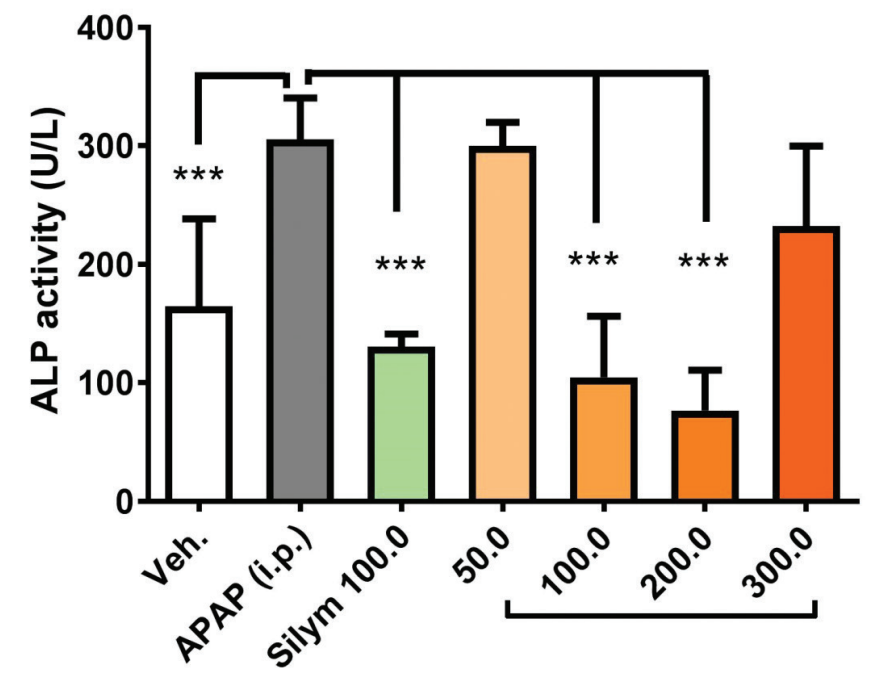

Treatments with CEBc (mg/kg p.o.)

Figure 3. Influence of $B$. crispa $(\mathrm{CEBc})$ given orally to mice on serum ALP activity (U/L) after acute hepatitis induced by paracetamol (APAP $350 \mathrm{mg} / \mathrm{kg}$ ). Each bar represents the mean $\pm \mathrm{SD}(n=6)$. Statistical analysis was performed using ANOVA, followed by Dunnett's multiple comparison test. ${ }^{* * *} p<0.0002$, significantly different from vehicle (Veh.).

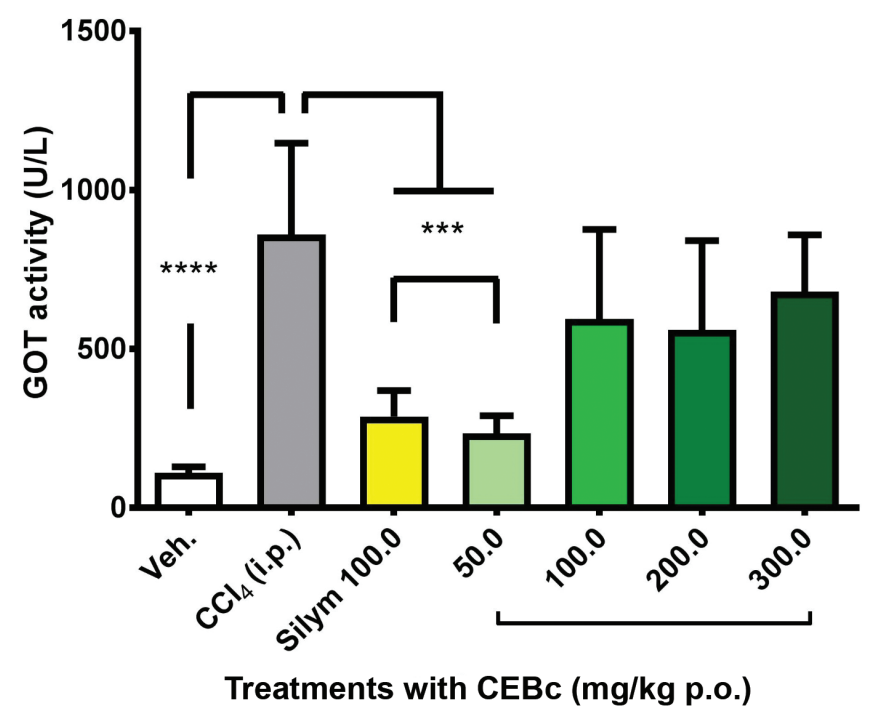

Figure 4. Influence of $B$. crispa $(\mathrm{CEBc})$ given orally to mice on serum GOT activity $(\mathrm{U} / \mathrm{L})$ after acute hepatitis induced by carbon tetrachloride $\left(\mathrm{CCl}_{4} 1 \%\right)$. Each bar represents the mean $\pm \mathrm{SD}(n=6)$. Statistical analysis was performed using ANOVA, followed by Dunnett's multiple comparison test. ${ }^{* * * *} p<$ $0.0001 ; * * *<0.0002$, significantly different from vehicle (Veh.).
Correspondingly, 5 days of oral pretreatment of mice with CEBc (50.0, 240.5 $\pm 51.2 ; 100.0,252.8 \pm 48.39$; and 200.0, $227.2 \pm 51.08, \mathrm{mg} / \mathrm{kg} ; \mathrm{U} / \mathrm{L}$, respectively; $p<0.0021)$ significantly reduced the $\mathrm{CCl}_{4}$-induced elevation of the serum level of ALP as far as $34 \%$. Furthermore, silymarin $(228.8 \pm 50.32 \mathrm{U} / \mathrm{L} ; p<0.0021$, positive control) induced a significant protecting effect on liver damage visualized by a reduced serum ALP level in comparison to pathological control (346 $\pm 9.539 \mathrm{U} / \mathrm{L}$ ) by $34 \%$ (Fig. 6). However,

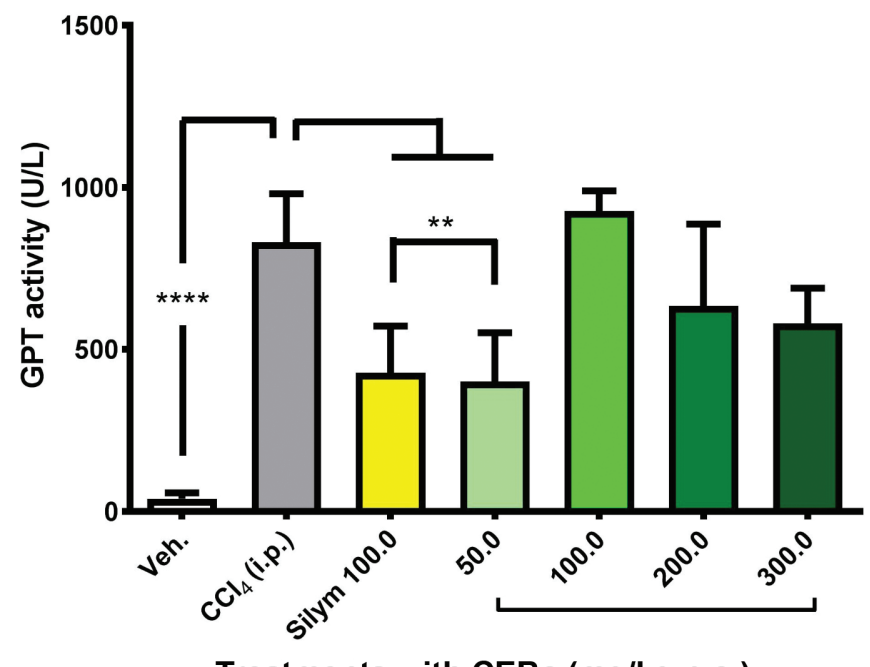

Figure 5. Influence of $B$. crispa $(\mathrm{CEBc})$ given orally to mice on serum GPT activity $(\mathrm{U} / \mathrm{L})$ after acute hepatitis induced by carbon tetrachloride $\left(\mathrm{CCl}_{4} 1 \%\right)$. Each bar represents the mean \pm SD $(n=6)$. Statistical analysis was performed using ANOVA, followed by Dunnett's multiple comparison test. ${ }^{* * *} p<$ $0.0001 ; * *<0.0021$, significantly different from vehicle (Veh.).

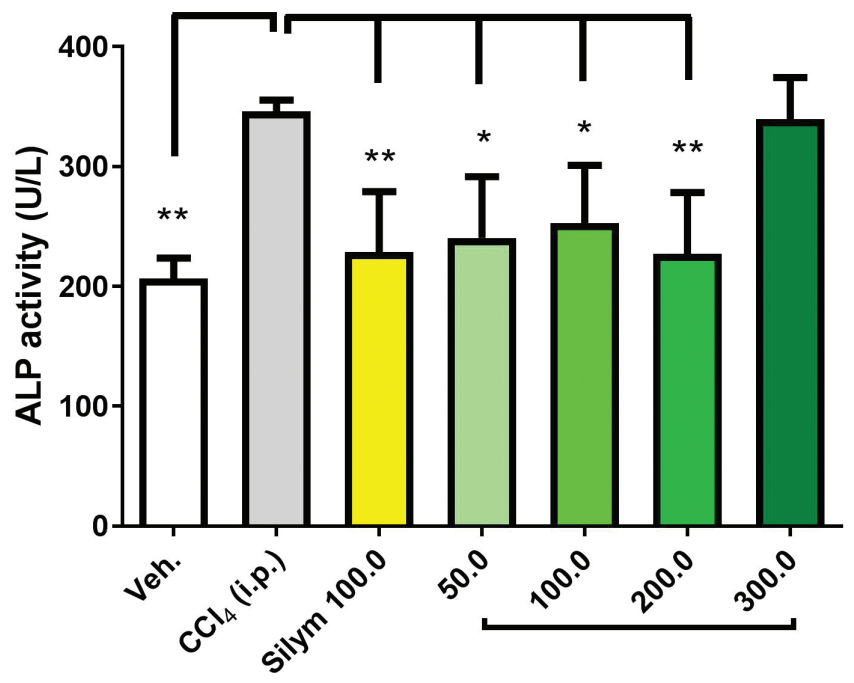

Treatments with CEBc (mg/kg p.o.)

Figure 6. Influence of B. crispa (CEBc) given orally to mice on serum ALP activity (U/L) after acute hepatitis induced by carbon tetrachloride $\left(\mathrm{CCl}_{4} 1 \%\right)$. Each bar represents the mean $\pm \mathrm{SD}(n=6)$. Statistical analysis was performed using ANOVA, followed by Dunnett's multiple comparison test. $* * p<0.0021$; ${ }^{*} p<0.0332$, significantly different from vehicle (Veh.). 
$300.0 \mathrm{mg} / \mathrm{kg}$ of CEBc $(339.4 \pm 34.85 \mathrm{U} / \mathrm{L})$ did not modify the ALP level which increased after liver injury induced by $\mathrm{CCl}_{4}$.

\section{DISCUSSION}

The administration of hepatoprotective drugs may induce the hepatocytes to resist the toxic effect of toxic agents, such as APAP and $\mathrm{CCl}_{4}$ among others (Somasundaram et al., 2010). Measuring the serum level of GPT, GOT, and ALP usually is the initial step involving the evaluation of hepatic conditions after viral or chemically induced injuries (Sun et al., 2018). A significant elevation of such enzymes induced by APAP and $\mathrm{CCl}_{4}$ was observed in this study, showing both hepatocellular and biliary injuries (Essien et al., 2013). Indeed, CEBc showed significant hepatoprotective activity, which was comparable with the standard liver-protecting drug silymarin. Therefore, a significant reduction of the APAP and $\mathrm{CCl}_{4}$-induced elevation of the serum level of these parameters was observed in mice treated with $\mathrm{CEBc}$, revealing a significant protective effect in comparison to APAP- and $\mathrm{CCl}_{4}$-treated groups.

In the literature, comparable findings to our results have been reported for Artemisia asiatica (Ryu et al., 1998), Cassia fistula (Bhakta et al., 2001), Cassia occidentalis (Yadav et al., 2010), Litchi chinensis (Bhoopat et al., 2011), and Sorbus pohuashanensis (Yin et al., 2019), among others. The serum rises in transaminases (GPT and GOT) and ALP, enzymes of cytoplasmic location, have been attributed to the damaged structural integrity of the liver (Ryu et al., 1998), allowing this enzyme to release into the blood stream after cell injury or death. Reversing the effects induced by treatment using phytopharmaceuticals or plants are common practices in traditional medicine (He et al., 2004). Phytochemicals such as citrus flavonoids, red wine polyphenols, Garcinia, Gymnema, Ginkgo, Ephedra sinica, Camellia sinensis, Silybum, Guarana, Eleuthero, Allium sativum, and Ocimum basilicum extracts were studied against the massive liver injuries induced by APAP with an auspicious counteracting effect on transaminases, oxidative stress, and DNA fragmentation in rats (Ray et al., 2006). It was observed that curcumin and its derivatives (octahydrocurcumin and tetrahydrocurcumin) possess a satisfactory hepatoprotective effect on mice through restoring antioxidant status, inhibiting CYP2E1, and activating Keap1-Nrf2 pathway, which might represent effective antioxidants for clinical use (Luo et al., 2019). Mice with a chronic liver injury and fibrosis induced by $\mathrm{CCl}_{4}$ were markedly ameliorated by polydatin (a glucoside of resveratrol) through inhibition of oxidative stress and inflammation. The levels of serum transaminases (GPT and GOT) and inflammatory mediators responsible for fibrosis were clearly modified by polydatin, reducing chronic oxidative stress and inflammation induced by $\mathrm{CCl}_{4}$ treatment (Zhao et al., 2017). A protective mechanism of aqueous leaves extract of Eucalyptus obliqua, probably due to its ability to reinforce the antioxidant defense system of Wistar rats submitted to $\mathrm{CCl}_{4}$-mediated liver damage, was established by Sabiu et al. (2017). Total flavonoids from Cyclocarya paliurus exert a potent protective effect against $\mathrm{CCl}_{4}$-induced acute liver injury in mice. The effect appears to be closely associated with the activity of flavonoids from $C$. paliurus that attenuated the transaminase increase induced by $\mathrm{CCl}_{4}$ and improved the defense antioxidant status of liver (Xie et al., 2018).
The mechanism of attenuating effect of $B$. crispa in acute chemically induced liver injury in mice is unknown. Our findings showed a protective effect of B. crispa using two different liver injury models. However, the presence of flavonoids, saponins, steroids, and triterpenes (Velázquez et al., 2019) could induce a minimizing oxidative stress in the liver in a similar way as mentioned by several studies present in the literature. The protective effect of $B$. crispa against acetaminophen-induced liver damage appears to be in a dosedependent manner according to the serum transaminases and ALP level. However, the attenuating effect of B. crispa on the elevation of transaminase and ALP induced by $\mathrm{CCl}_{4}$ was not dosedependent. At least, these divergences probably are mainly due to the hepatotoxicity models used. Severity of liver damage induced by $\mathrm{CCl}_{4}$ was greater than APAP, considering the observed serum level of transaminases and ALP. $\mathrm{CCl}_{4}$, at a suitable dose, induced widespread necrosis in the centrilobular region of the liver around the central veins (Bhoopat et al., 2011). Indeed, the potency of doses of hepatotoxins used in this study is not comparable, and also, the sensitivity of animals submitted to injuries was not evaluated. The mechanism of injuries is also complex with shared (oxidative stress and generation of reactive oxygen species) and uncommon (tissue factor activation) mechanisms of liver damage (Abdel-Bakky et al., 2015; Woolbright and Jaeschke, 2018). In the same genus, a hepatoprotective effect of $B$. trimera against acetaminophen-induced toxic hepatitis was found (Pádua et al., 2014). Also, a significant free radical scavenging activity in aqueous extracts obtained from aerial parts of $B$. cordifolia and B. crispa (Asteraceae) correlating to a significant antioxidant activity was found (Desmarchelier et al., 1997). Understanding of pathophysiology of drug-induced damage and the principles of liver protective activity of phytochemicals could guide future drug development and help prevention of clinical trial failure. Nevertheless, it is known that silymarin has poor solubility resulting in low bioavailability. This property has conditioned the great advances made on the development of novel delivery systems and pharmaceutical formulation with improved bioavailability for this bioactive natural compound and its derivatives (Bilia et al., 2017; Theodosiou et al., 2014; Yang et al., 2015). The bioavailability of $\mathrm{CEBc}$ is unknown and probably reduced activity of higher dose could be explained by a potential poor absorption from intestinal tract. Therefore, a good candidate for hepatoprotective drug and bioavailability of phytomedicine should be well defined for a safe and effective clinical use. Furthermore, the use of new delivery systems or pharmaceutical formulations that enhances bioavailability of poorly water-soluble compounds may improve effectiveness already obtained (Domitrović and Potočnjak, 2016). Finally, complementary molecular and histological studies are in a way needed to clarify the mechanism of attenuating effect of $B$. crispa on acute liver injury using mice.

\section{CONCLUSION}

Based on the results, it was evident that crude extract obtained from the aerial part of B. crispa has a protecting effect on chemically induced acute liver injury, considering the transaminase and ALP serum level in two models of liver injury. The active compound(s) and mechanism of protection remain unclear and are in a way to be solved soon in new chemical and pharmacological studies. 


\section{ACKNOWLEDGMENTS}

This work was performed under the financial support of Faculty of Chemical Sciences of the National University of Asuncion and Consejo Nacional de Ciencia y Tecnología (CONACYT) (PROCIENCIA Grant code 14-INV-325). The authors acknowledge the Department of Botany from Faculty of Chemical Sciences for supporting them with the identification of plant material.

\section{AUTHORS' CONTRIBUTIONS}

AMV and EMGD contributed to conception and design. AMV and DAI contributed to administrative support. OH, YM, and MAC-B contributed to collection and assembly of data. MLK, $\mathrm{MCH}-\mathrm{I}$, and DAI contributed to data analysis and interpretation and manuscript writing. AMV, EMGD, OH, YM, MAC-B, MLK, MCH-I, and DAI contributed to the final approval of the manuscript.

\section{CONFLICT OF INTEREST}

The authors declared that they have no conflicts of interest.

\section{FUNDING}

\section{None.}

\section{REFERENCES}

Abdel-Bakky MS, Helal GK, El-Sayed EM, Saad AS. Carbon tetrachloride-induced liver injury in mice is tissue factor dependent. Environ Toxicol Pharmacol, 2015; 39:1199-205.

Aparecida F, Mota L, Ferreira DM, Galuppo LF, Borato DG, Bruno T, Prando L, Luiz E, Lourenço B, Lauriano R, Strapasson B, Élida M, Stefanello A, Fernanda M, Werner DP, Acco A. Hydroethanolic extract of Baccharis trimera promotes gastroprotection and healing of acute and chronic gastric ulcers induced by ethanol and acetic acid. Naunyn Schmiedebergs Arch Pharmacol, 2016; 389:985-98.

Basualdo I, Soria N, Ortiz M, Degen R. Plantas medicinales comercializadas en los mercados de Asunción y Gran Asunción. Rojasiana, 2004; 6:95-112.

Bhakta T, Banerjee S, Mandal SC, Maity TK, Saha BP, Pal M. Hepatoprotective activity of Cassia fistula leaf extract. Phytomedicine, 2001; 8:220-24.

Bhoopat L, Srichairatanakool S, Kanjanapothi D, Taesotikul T, Thananchai H, Bhoopat T. Hepatoprotective effects of lychee (Litchi chinensis Sonn.): a combination of antioxidant and anti-apoptotic activities. J Ethnopharmacol, 2011; 136:55-66.

Bilia AR, Piazzini V, Guccione C, Risaliti L, Asprea M, Capecchi G, Bergonzi MC. Improving on nature: the role of nanomedicine in the development of clinical natural drugs. Planta Med, 2017; 83:366-81.

Cáceres MS, Machaín Singer AM. Manual de uso de hierbas medicinales del Paraguay. Proyecto Paraguay: Farmacopea tradicional, Patrimonio Cultural y Estrategia de Desarrollo. Fundación Celestina Pérez de Almada (Paraguay). UNESCO Oficina Regional de Ciencia y Tecnología para América Latina y el Caribe, 73 p, 2001.

da Silva ARH, Lopes LQS, Cassanego GB, de Jesus PR, Figueredo KC, Santos RCV, Lopes GHH, de Freitas Bauermann L. Acute toxicity and antimicrobial activity of leaf tincture Baccharis trimera (Less). Biomed J, 2018; 41:194-201.

Desmarchelier C, Novoa Bermudez MJ, Coussio J, Ciccia G, Boveris A. Antioxidant and prooxidant activities in aqueous extracts of Argentine plants. Pharm Biol, 1997; 35:116-20.

Domitrović R, Potočnjak I. A comprehensive overview of hepatoprotective natural compounds: mechanism of action and clinical perspectives. Arch Toxicol, 2016; 90(1):39-79.

Essien NA, Iwara A, Mgbeje BIA, Igile GO, Egbung GE, Ebong PE. Lipid profile and hepatoprotective effects of combined leaf extracts of Azadirachta Indica (Neem) and Peristrophe bicalyculata in alloxan-induced diabetic rats. Int J Phytomedicine, 2013; 5:159-62.
He Q, Kim J, Sharma RP. Silymarin protects against liver damage in BALB/c mice exposed to fumonisin B 1 despite increasing accumulation of free sphingoid bases. Toxicol Sci, 2004; 80:335-42.

Ibarrola DA, Degen RL, Alvarenga NL, Ferro EA, HellionIbarrola MC. Catálogo ilustrado de 80 plantas medicinales del Paraguay. Asunción, Paraguay: Editorial AGR S.A., 2011.

Lancaster E, Hiatt J, Zarrinpar A. Acetaminophen hepatotoxicity: an updated review. Arch Toxicol, 2015; 89:193-9.

Luo DD, Chen JF, Liu JJ, Xie JH, Zhang ZB, Gu JY, Zhuo JY, Huang S, Su ZR, Sun ZH. Tetrahydrocurcumin and octahydrocurcumin, the primary and final hydrogenated metabolites of curcumin, possess superior hepatic-protective effect against acetaminophen-induced liver injury: role of CYP2E1 and Keap1-Nrf2 pathway. Food Chem Toxicol, 2019; 123:349-62.

Mayoral W, Lewis JH. Drug-induced liver disease. Curr Opin Gastroenterol, 2000; 16:231-8.

McGill MR, Jaeschke H. Animal models of drug-induced liver injury. Biochim Biophys Acta - Mol Basis Dis, 2019; 1985(5): 1031-9.

McGill MR, Williams CD, Xie Y, Ramachandran A, Jaeschke H. Acetaminophen-induced liver injury in rats and mice: comparison of protein adducts, mitochondrial dysfunction, and oxidative stress in the mechanism of toxicity. Toxicol Appl Pharmacol, 2012; 264:387-94.

Pádua BDC, Rossoni Júnior JV, De Brito Magalhães CL, Chaves MM, Silva ME, Pedrosa ML, Souza GHB De, Brandão GC, Rodrigues IV, Lima WG, Costa DC. Protective effect of Baccharis trimera extract on acute hepatic injury in a model of inflammation induced by acetaminophen. Mediators Inflamm, 2014; 2014:196598.

Ray SD, Patel N, Shah N, Nagori A, Naqvi A, Stohs SJ. Preexposure to a novel nutritional mixture containing a series of phytochemicals prevents acetaminophen-induced programmed and unprogrammed cell deaths by enhancing BCL-XL expression and minimizing oxidative stress in the liver. Mol Cell Biochem, 2006; 293:119-36.

Ryu BK, Ahn BO, Oh TY, Kim SH, Kim WB, Lee EB Studies on protective effect of DA-9601, Artemisia asiatica extract, on acetaminophen- and CCl4-induced liver damage in rats. Arch Pharm Res, $1998 ; 21: 508-13$.

Sabiu S, Ajani EO, Sunmonu TO, Balogun FO, Ashafa AOT, Othman RB, Olowa SK. Mechanism of hepatoprotective potential of aqueous leaves extract of Eucalyptus obliqua (Myrtaceae) in carbon tetrachloride intoxicated Wistar rats. J Appl Pharm Sci, 2017; 7:183-90.

Salgueiro ACF, Folmer V, Bassante FEM, Cardoso MHS, da Rosa HS, Puntel GO. Predictive antidiabetic activities of plants used by persons with Diabetes mellitus. Complement Ther Med, 2018; 41:1-9.

Somasundaram A, Karthikeyan R, Velmurugan V, Dhandapani B, Raja M. Evaluation of hepatoprotective activity of Kyllinga nemoralis (Hutch \& Dalz) rhizomes. J Ethnopharmacol, 2010; 127:555-7.

Stolz ED, Müller LG, Trojan-Rodrigues M, Baumhardt E, Ritter MR, Rates SMK. Survey of plants popularly used for pain relief in Rio Grande do Sul, southern Brazil. Brazilian J Pharmacogn, 2014; 24:185-96.

Sun J, Wen X, Liu J, Kan J, Qian C, Wu C, Jin C. Protective effect of an arabinogalactan from black soybean against carbon tetrachlorideinduced acute liver injury in mice. Int J Biol Macromol, 2018; 117:659-64.

Theodosiou E, Stamatis H, Kolisis F. Bioavailability of silymarin flavonolignans : drug formulations and biotransformation. Phytochem Rev, $2014 ; 13: 1-18$

Velázquez AM, Mallorquín ZE, Montalbetti Y, Campuzanobublitz MA, Hellión-ibarrola MC, Kennedy ML, Ibarrola DA. Assessment of general effects and gastrointestinal prokinetic activity of Baccharis crispa in mice. J Appl Biol Biotechnol, 2019; 7:30-4.

Wang R, Kong J, Wang D, Lien LLM, Lien EJC. A survey of Chinese herbal ingredients with liver protection activities. Chin Med, 2007; $2: 1-8$.

Woolbright BL, Jaeschke H. Mechanisms of inflammatory liver injury and drug-induced hepatotoxicity. Curr Pharmacol Rep, 2018; 4:346-57.

World Health Organization (WHO). WHO traditional medicine strategy 2014-2023. World Health Organization, Geneva, Switzerland, pp $1-76,2013$ 
Wu YL, Piao DM, Han XH, Nan JX. Protective effects of salidroside against acetaminophen-induced Toxicity in Mice. Biol Pharm Bull, 2008; 31:1523-9.

Xie J, Wang W, Dong C, Huang L, Wang H, Li C, Nie S, Xie M. Protective effect of flavonoids from Cyclocarya paliurus leaves against carbon tetrachloride-induced acute liver injury in mice. Food Chem Toxicol, 2018; 119:392-9.

Yadav JP, Arya V, Yadav S, Panghal M, Kumar S, Dhankhar S. Cassia occidentalis L.: a review on its ethnobotany, phytochemical and pharmacological profile. Fitoterapia, 2010; 81:223-30.

Yang G, Zhao Y, Feng N, Zhang Y, Liu Y, Dang B. Improved dissolution and bioavailability of silymarin delivered by a solid dispersion prepared using supercritical fluids. Asian J Pharm Sci, 2015; 10:194-202.

Yin Y, Zhang Y, Li H, Zhao Y, Cai E, Zhu H, Li P, Liu J. Triterpenoids from fruits of Sorbus pohuashanensis inhibit acetaminophen-induced acute liver injury in mice. Biomed Pharmacother, 2019; 109:493-502.
Zhao X, Li R, Liu Y, Zhang X, Zhang M, Zeng Z, Wu L, Gao $X$, Lan T, Wang Y. Polydatin protects against carbon tetrachloride-induced liver fibrosis in mice. Arch Biochem Biophys, 2017; 629:1-7.

\section{How to cite this article:}

Velázquez AM, Diarte EMG, Heinichen OY, Montalbetti Y, Campuzano-Bublitz MA, Kennedy ML, Hellion-Ibarrola MDC, Ibarrola DA. B. crispa attenuates toxic hepatitis induced by acetaminophen and carbon tetrachloride in mice. J Appl Pharm Sci, 2020; 10(11):110-116. 